\title{
Coastal State Competences Regarding Safety of Maritime Navigation: recent trends
}

\author{
Competência dos Estados Costeiros Relativa à Segurança da Navegação \\ Marítima: tendências recentes
}

\author{
Roberto Virzo \\ University of Florida, Florida - Estados Unidos \\ Università degli Studi del Sannio, Benevento - Itália
}

\begin{abstract}
The erosion of the freedom of the seas regime that has been taking place especially since the end of World War II seems to be continuing more gradually and in a different manner. In order to protect the interests of the international community coinciding more or less with their own needs, the coastal states, the archipelagic states, the regional fishing organizations for the high seas and the International Seabed Authority are ever more often exercising functions that previously had been carried out above all by the flag state. In this work we examine the evolution of international law governing the safety of maritime navigation. The analysis covers, first, the cooperation between coastal states and the International Maritime Organization and, subsequently, coastal states' independently exercisable competences: both topics concerning the reinforcement of the safety maritime navigation.
\end{abstract}

Keywords: International Law of the Seas. Safety of Maritime Navigation. Coastal States.
Resumo: A erosão do regime da liberdade dos mares que se tem verificado especialmente desde o fim da Segunda Guerra Mundial parece estar prosseguindo de modo mais intenso e de outra maneira. A fim de proteger os interesses da comunidade internacional que coincidem mais ou menos com suas próprias necessidades, os Estados costeiros, os Estados arquipelágicos, as organizações regionais de pesca em alto-mar e a Autoridade Internacional dos Fundos Marinhos estão cada vez mais exercendo funções que anteriormente eram levadas a efeito, sobretudo, pelo Estado de bandeira. Neste trabalho examina-se a evolução do direito internacional que regula a segurança da navegação marítima. A análise abrange, em primeiro lugar, a cooperação entre Estados costeiros e a Organização Marítima Internacional e, na sequência, as competências exercitáveis independentemente dos Estados costeiros; ambos os tópicos relacionados à regulação da segurança da navegação marítima.

Palavras-chave: Direito Internacional Marítimo. Segurança da Navegação Marítima. Estados Costeiros.

Recebido em: 1\%/09/2015

Revisado em: 05/10/2015

Aprovado em: 13/10/2015 


\section{The Competences of Coastal States Regarding the Safety of Navigation and the Erosion of the Freedom of the Seas Regime}

The erosion of the freedom of the seas regime that has been taking place, especially since the end of World War II, at an ever-increasing pace up to the beginning of the 1990 s, seems to be continuing more gradually and in a different manner.

It is a known fact that the main effects triggered by the acute phase of that process of erosion were the reduction of free areas of sea, the rise of the sovereignty of coastal states and archipelagic states over territorial seas, the exercise by those same states of special 'sovereign rights', the powers of control or jurisdiction over sui generis maritime zones and the continental shelf and evolution of the legal nature of some competences of the flag state transformed from exclusive to concurrent ones. ${ }^{1}$

Currently, the spatial expansion of the rights and powers of coastal states and archipelagic states has been attenuated. For example, there has been no endorsement of unilateral attempts by some coastal states to exercise powers of control aimed at managing and rationally conserving some fish stocks in areas of the high seas adjacent to their exclusive economic zones (EEZ). ${ }^{2}$ Neither has any coastal state so far proclaimed a marine protected area $^{3}$ beyond 200 nautical miles of their EEZ.

Moreover, while it is true that 'creeping jurisdiction' cannot be said to have completely stopped, this is only because the Commission on the Limits of the Continental Shelf (CLCS) set up by the United Nations

\footnotetext{
1 In this regard, see T. Scovazzi, 'The Evolution of the International Law of the Sea: New Issues, New Challenges', Recueil des Cours de l'Académie de droit international de la Haye, Vol. 286, 2000, pp. 39-244.

2 For an analysis of the practice and legislation of some coastal states that in the 1990s proposed the establishment of these new maritime zones, see - also for the other literature cited therein - R. Casado Raigón, 'La liberté de la pêche en haute mer', in D. Vignes, G. Cataldi \& R. Casado Raigón (Eds.), Le droit international de la pêche maritime, Bruylant, Brussels, 2000, pp. 128-157.

3 On some types of these marine protected areas, see infra $\S 12.4$.
} 
Convention on the Law of the Sea (UNCLOS) 4 is currently completing its examination of the requests of some coastal states to extend their own continental shelves beyond the 200 nautical mile limit. ${ }^{5}$ Therefore it is not a further case of expansion of the competences ratione loci of the coastal state, but rather implementation of an optional provision of UNCLOS, ${ }^{6}$ which for that matter is a convention that was negotiated and concluded precisely at a time coinciding with the most determined efforts of coastal states to claim various types of rights over vast tracts of the sea, land and seabed. It has been observed that probably if UNCLOS had been drawn up in more recent times, the legal rules governing the continental shelf beyond 200 nautical miles would be framed differently. ${ }^{7}$

However, as mentioned above, the process of erosion of the freedom of the seas regime cannot be considered as having ground to a halt. Rather than further reduce space on the high seas, ${ }^{8}$ today the process tends to encroach on the traditional delimitation of the rights and competences stemming from that regime - delimitation notoriously skewed in favour of the flag state - and, in the final analysis, to condition the legal regulation of activities at sea. Indeed, one can witness a progressive granting of some of those rights and powers also to the states and the international organizations among whom the maritime space totally or partially removed from the freedom of the seas has been divided up. In other words, in order to protect the interests of the international community coinciding more or less with their own needs, the coastal states, the archipelagic states,

4 The UNCLOS was signed at Montego Bay on 10 December 1982 and entered into force on 16 November 1994. See 1833 UNTS 397.

5 Art. 76, para. 8, UNCLOS. See V.J.M. Tassin, Les défis de l'extension du plateau continental. La consécration d'un nouveau rapport de l'Etat à son territoire, Pedone, Paris, 2013.

6 Art. 76, para. 8, UNCLOS.

7 A. Del Vecchio, 'Piattaforma continentale, Postilla di aggiornamento', in Enciclopedia Giuridica, Aggiornamento, Vol. XVII, Istituto della enciclopedia italiana Treccani, Rome, 2008, p. 3.

8 For a different interpretation of the practice of the coastal states, see G. Andreone, 'Les émergences environnementales et la stratégie de la sécurité maritime', in G. Andreone, A. Caligiuri \& G. Cataldi (Eds.), Droit de la mer et émergences environnementales, Editoriale Scientifica, Naples, 2012, pp. 59-64. 
the regional fishing organizations for the high seas and the International Seabed Authority are ever more often exercising functions that previously had been carried out above all by the flag state.

In this work we shall be examining, for example, the evolution of international law governing the safety of maritime navigation. The development of the rules in question emblematically reflects the trend described above. In particular, it will be noted that that trend envisages an ever greater role for coastal states ${ }^{9}$ and a progressive reduction of the competences traditionally enjoyed in the main by the flag state.

\section{Brief Remarks on the Competences of Port States Regarding the Safety of Navigation}

We shall not be dwelling on the competences that the coastal state exercises in relation to the safety of maritime navigation in its capacity as port state ${ }^{10}$ because port state control ${ }^{11}$ is covered in a specific chapter of this book. ${ }^{12}$

However, it is worth clarifying that reference in the previous section hereof to the traditional 'principal' competence of the flag state re-

9 On the competences of the European Union in the matter of the safety of maritime navigation, see - also for the other literature cited therein - H. Ringbom, The EU Maritime Safety Policy and International Law, Martinus Nijhoff, Leiden, 2008; A. Del Vecchio, 'Protection et sécurité dans les transports maritimes: les mesures de l'Union européenne', in J.M. Sobrino Heredia (Ed.), Sûreté maritime et violence en mer, Bruylant, Brussels, 2011, pp. 357-379; L. Schiano Di Pepe, 'Prevention and Management of the Environmental Emergencies at Sea in the European Union's Third Maritime Safety Package', in Andreone, Caligiuri \& Cataldi 2012, pp. 363-385.

10 Moreover, it should be noted that at times the port state may exercise certain competences at the request of another coastal state. See, e.g., Art. 218, para. 2, UNCLOS. 11 E.J. Molenar, 'Port State Jurisdiction', in R. Wolfrum (Ed.), The Max Planck Encyclopaedia of Public International Law, Vol. VIII, Oxford University Press, Oxford, 2012, p. 355, prefers to speak in terms of port state jurisdiction, which "is broader than the term 'port state control"'. Indeed, "Port State Jurisdiction is the competence of States to exercise prescriptive - or legislative - and enforcement jurisdiction over foreign vessels within their ports."

12 See E. Turco Bulgherini, 'Port State Control', in this book. 
garding the safety of maritime navigation is explained, firstly, by the fact that even the earliest treaties on this matter granted limited powers of control on ship safety to port states, ${ }^{13}$ some of which had actually already adopted domestic legislation to avoid a situation whereby safety levels would be independently and at times inadequately set by private parties. ${ }^{14}$ Indeed, these initial conventions were concluded for a number of reasons, including the following: (1) "unilateral initiatives could not have an incisive effect on important aspects of ship safety that took place in areas of the sea outside the governmental authority of the states" and (2) it became fundamental to lay down rules that were generally uniform in this field. ${ }^{15}$

Secondly, because - as noted also in the above-mentioned essay on port state control in this book ${ }^{16}$ - the weaknesses of the safety of navigation regime centred mainly on flag state control (discussed later) facilitated the inclusion in UNCLOS, International Maritime Organization (IMO) agreements ${ }^{17}$ and regional agreements between port authorities (so-called Memorandums of Understanding ${ }^{18}$ ) of provisions granting further competences to port states.

13 See, e.g., Art. 59 of the Convention for the Safety of Life at Sea, which was signed in London on 20 January 1914 and entered into force on 1 July 1915, available at <www. imo.org >.

14 One can mention, e.g., the British Merchant Shipping Act of 21 December 1906 $<$ www.legislation.gov.uk $>$ and the Act to Promote the Welfare of the American Seamen in the Merchant Marine of the United States of America of 4 March 1915, in United States Statutes at Large, Vol. 38, pp. 1164-1185. In this regard, see P. Boisson, Safety at Sea, Policies, Regulations and International Law, Bureau Veritas, Paris, 1999, pp. 45-53 and P. Celle, 'Il Port State Control nel diritto internazionale', in Studi in onore di Umberto Leanza, Editoriale Scientifica, Naples, 2008, pp. 1570-1573.

15 Celle 2008, p. 1572.

16 Turco Bulgherini 2013.

17 On the IMO and the conventions adopted under its auspices, see the thorough monograph H. Lefebvre-Chalain, La stratégie normative de l'Organization Maritime (OMI), PUAM, Aix-en-Provence, 2012.

18 See P. Simone, 'Contenuti e natura giuridica dei memorandum of understanding sul Port State Control', in R. Tranquilli-Leali \& E.G. Rosafio (Eds.), Sicurezza, navigazione e trasporto, Giuffré, Milan, 2008, pp. 267-315. 


\section{Cooperation between Coastal States and the International Maritime Organization Regarding the Safety of Maritime Navigation}

While it may not be necessary to dwell further on the rights, powers and controls that coastal states may exercise regarding the safety of navigation in their own ports and internal waters, it is worth reflecting on the competences that international conventions ever more frequently grant them over their territorial seas and sui generis maritime zones.

They are competences that can be divided into two large categories, specifically, those that a coastal state exercises in conjunction with the IMO and those that it can exercise alone.

The first category includes competences regarding the safety of maritime navigation, where an important role has been assigned also to the IMO in order to avoid a situation where the functions in question are exercised by coastal states with too much discretion to the point of imposing disproportionate limits on the right of passage or the freedom of navigation of other states. In fact, the various provisions of conventions that grant competences within this category to the coastal state do not lay down objective conditions governing actual exercise thereof. Given that those rules - which represent an evolution of those negotiated at the end of the 1970s to regulate intervention on the high seas in cases of oil pollution $^{19}$ - exclude a coastal state on its own from deciding on actual intervention and require the involvement of the IMO. This also holds true for some UNCLOS provisions that generally refer to the competent international organization, given that - according to the UN Secretary General's

${ }_{19}$ International Convention Relating to Intervention on the High Seas in Cases of Oil Pollution Casualties, Brussels, 29 November 1969; entry into force, 6 May 1975. See 970 UNTS 212 . 
report of 20 October $1997^{20}$ and the predominant literature ${ }^{21}$ - the latter can be none other than the IMO.

Commencing therefore from UNCLOS, reference must be made above all to Articles 22, 41 and, as regards a particular type of coastal state, i.e. an archipelagic state, Article 53. The three provisions envisage the establishment for reasons of safety, of sea lanes or traffic separation schemes, respectively in the territorial sea, in straits used for international navigation and in archipelagic waters.

More in detail, under Article 22, the coastal state may "where necessary having regard to the safety of navigation, require foreign ships exercising the right of innocent passage through its territorial sea to use [...] sea lanes and traffic separation schemes" (paragraph 1), designated by it taking into account the recommendations of the competent international organization (paragraph 3(a)), which, as aforesaid, is recognized as being the IMO.

That provision, which does not set out the criteria for determining when the establishment of sea lanes and traffic separation schemes is to be deemed necessary for the safety of maritime navigation, seems to suggest that a coastal state, even if not a member of the IMO, must take into consideration the pertinent recommendations of that organization so as not to breach the prohibition against impeding foreign ships from exercising their right of innocent passage through its territorial sea. ${ }^{22}$ In other

20 GA A/52/491, 20 October 1997, Report of the UN Secretary General, Impact of the Entry into Force of the Unite Nations Convention of the Law of the Sea on Related, Existing or Proposed Instruments and Programmes, Section J, paras. 8 and 9.

21 See, e.g., B. Oxman, 'Environmental Protection in Archipelagic Waters and International Straits. The Role of the International Maritime Organization', International Journal of Marine and Coastal Law, Vol. 10, 1995, p. 467; D.R. Rothwell \& T. Stephens, The International Law of the Sea, Hart Publishing, Oxford, 2010, p. 221; T. Dux, Specially Protected Marine Areas in the Exclusive Economic Zone (EEZ), LIT Verlag, Berlin, 2011, p. 194.

22 In that sense, Oxman 1995, p. 476; E.J. Molenaar, Coastal State Jurisdiction over Vessel-Source Pollution, Kluwer Law International, The Hague, 1998, p. 204; E. Scalieris, L'exercise du pouvoir discrétionnaire de l'Etat côtier en droit de la mer, Pedone, Paris, 2011, p. 170. 
words, it is one of those cases in which the exhortation to comply with a non-binding recommendation of a given international organization flows from an international treaty other than the one setting up the organization in question. ${ }^{23}$

Even more incisive is the role of the IMO under Article 41, paragraph 4, and Article 53, paragraph 9, UNCLOS so much so that some writers maintain that the provisions imply a "cooperative legislative competence of an unusual kind" of the IMO with the coastal state or with the archipelagic state. ${ }^{24}$ In fact, pursuant to both of the provisions, "before designating or substituting sea lanes or prescribing or substituting traffic separation schemes," one or other of the states "shall refer proposals to the competent international organization with a view to their adoption." If the IMO approves those proposals, the state bordering a strait ${ }^{25}$ or the archipelagic state may designate, prescribe or substitute the said sea lanes or traffic separation schemes. Moreover "ships in transit passage [in archipelagic sea lanes passage] shall respect applicable sea lanes and traffic separation schemes established in accordance with" Article 41 or 53. ${ }^{26}$

Cooperation between coastal states and the IMO in the matter of the safety of navigation is also contemplated in the Annex to the International Convention for the Safety of Life at Sea (SOLAS). ${ }^{27}$ In Chapter V, headed Safety of Navigation, amended on various occasions, ${ }^{28}$ it is provided inter alia that a coastal state may request the IMO for authorization to adopt a

${ }^{23}$ Permit me to refer to R. Virzo, 'Gli atti delle organizzazioni internazionali', in A. Del Vecchio (Ed.), Diritto delle organizzazioni internazionali, Edizioni Scientifiche Italiane, Naples, 2012, pp. 126-127.

24 Oxman 1995, p. 479 and, agreeing with him, Scalieris 2011, p. 173.

25 For an examination of the pertinent practice, see M. Fornari, Il regime giuridico degli stretti utilizzati per la navigazione marittima, Giuffré, Milan, 2010.

26 See paras. 7 and 11 respectively of Arts. 41 and 53 UNCLOS.

27 That Convention was signed in London on 1 November 1974 and entered into force on 25 May 1980. See United Nations Treaty Series, Vol. 1184, p. 278 et seq. The Convention has been amended on a number of occasions, and reference should be made to the website $<$ www.imo.org $>$.

28 For our purposes the most important amendment was that approved by the Maritime Safety Committee of the IMO through Res. MSC.31 (63) of 23 May 1994. 
compulsory ship reporting system (SRS) ${ }^{29}$ in order to "contribute to safety of life of sea, safety and efficiency of navigation and/or protection of the marine environment" (Regulation 11 (a)). By installing an SRS in one's own territorial sea or maritime zones under one's jurisdiction, a coastal state seeks to obtain from ships, flying its own or a foreign flag, that pass through that maritime space the information necessary to identify them and know in advance what type of cargo and goods are on board. ${ }^{30}$ The gathering of information may allow the coastal state to promptly intervene and act in the best manner should an accident occur, ${ }^{31}$ which could give rise to a grave risk of marine pollution.

The mechanism provided for in Regulation 11 of Chapter V SOLAS is an incentive for coastal states to cooperate with the IMO. While it is true that pursuant to subparagraph d), "ship reporting systems not submitted to the Organization for adoption do not need to comply with this Regulation," nonetheless, firstly, also in this latter case "Governments implementing such systems are encouraged to follow, wherever possible, the guidelines and criteria developed by the Organization." 32 Secondly, in the absence of specific IMO authorization, it will be more difficult for the coastal state to demonstrate that its SRS does not violate the customary rules enshrined in UNCLOS relating to innocent passage or transit or the freedom of navigation. ${ }^{33}$ Thirdly, and what probably counts more for the coastal state, only an SRS

${ }_{29}$ On the international legal rules governing SRS, see the following among many in the literature: G. Plant, 'The Relationship Between International Rights and Environmental Protection: A Legal Analysis of Mandatory Ship Traffic Systems', in H. Ringbom (Ed.), Competing Norms in the Law of Marine Environmental Protection, Kluwer Law International, The Hague, 1997, pp. 11-29; G. Mapplebeck, 'Management of Navigation Through Vessel Traffic Services', in D. Rothwell \& S. Bateman, Navigational Rights and Freedoms of the New Law of the Sea, Kluwer Law International, The Hague, 2000, pp. 136-143; M.M. Comenale Pinto \& G. Spera, 'Profili giuridici dell'Automatic Identification System (AIS)', in Tranquilli-Leali \& Rosafio 2008, pp. 53-73.

30 Fornari 2010, p. 142.

31 Ibid.

32 SOLAS, V-11(d).

33 SOLAS, V-11(h). 
[...] adopted and implemented in accordance with the guidelines and criteria developed by the Organization pursuant to this regulation, shall be used by all ships or certain categories of ships carrying certain cargoes in accordance with the provisions of each system so adopted. ${ }^{34}$

\section{The Regulation of the Safety of Navigation in the "Special Ar- eas" under Article 211, Paragraph 6, UNCLOS and in the Par- ticularly Sensitive Sea Areas (PSSA)}

Cooperation between coastal states and the IMO regarding safety of maritime navigation is also required when certain maritime zones for the protection of the marine environment are established.

Consider, for example, ${ }^{35}$ the special areas under Article 211, paragraph 6, UNCLOS. Regarding pollution from vessels, the first paragraph of Article 211 provides above all that the states parties to the Convention must - acting through the competent international organization or general diplomatic conference - establish rules, standards and routing systems to prevent pollution of the marine environment from vessels and to "minimize the threat of accidents, which might cause pollution of the marine environment, including the coastlines, and pollution damage to related interests of coastal states." Neither paragraph 1 nor the other paragraphs

\footnotetext{
34 SOLAS, V-11(a). On this point see Scalieris 2011, pp. 170-172.

35 For an analysis of the various marine protected areas that could be established for a variety of purposes in EEZs, see Dux 2011, passim; for those on the high seas, see T. Scovazzi, 'Marine Protected Areas on the High Seas: Some Legal and Policy Considerations', International Journal of Marine and Coastal Law, Vol. 19, 2004, pp. 1-17. See also N. Matz, 'Protected Areas in International Nature Conservation Law: Can State Obtain Compensation for Their Establishment?', Zeitschrift für ausländisches öffentliches Recht und Völkerreckt, Vol. 62, 2002, pp. 693-716; D. Enríquez, 'El florecimiento de las zonas marinas especialmente sensibles: hacia una nueva "batailla libresca" en pleno siglo XXI?', Anuario mexicano de derecho internacional, Vol. 5, 2005, pp. 453-575; Y. Tanaka, The International Law of the Sea, Cambridge University Press, Cambridge, 2012, pp. 324-333; S. Wolf, 'Marine Protected Areas', in Wolfrum 2012, Vol. VI, pp. 1056-1063.
} 
of Article 211 mention safety of navigation. However, reference thereto is implicit. In fact, it is worth remembering that by safety is meant the safety of navigation that risks being compromised by technical accidents caused, for example, by the malfunctioning of the ship or human error $^{36}$ and that rules on both safety and security ${ }^{37}$ are designed to safeguard persons on board ships (passengers and crew), things (ships, cargo and other items on board) and last but not least the marine environment. ${ }^{38}$

Pursuant to paragraph 2 of Article 211, the international rules and standards serve as parameters for domestic legislation that the states parties to the Convention must apply to the ships that fly their flag. However, there are some states that have not ratified either UNCLOS or other important conventions on pollution from vessels and the safety of navigation or that are contracting parties solely to the Montego Bay Convention or just some of the other conventions. This favours resort to flags of convenience. Indeed, some shipowners, so as to avoid complying with especially strict domestic laws that could have a bearing on their costs and hence profits, register ships with states that are bound by the smallest number of international agreements containing obligations regarding safety or that, though parties to the agreements, have neither the ability nor the will to carry out checks on compliance with the above-mentioned international rules and standards.

Also with a view to tackling that problem, UNCLOS provides that a coastal state - in addition to being able to adopt enforcement measures under Article 220 against all merchant ships, including foreign ones, in areas of the sea under its jurisdiction or over which it exercises rights, being able to adopt laws and regulations regarding pollution from ships applicable in the territorial sea $\mathrm{s}^{39}$ and being able, if necessary, to take arbitral or court proceedings pursuant to Articles 286 and 287 against a flag state

\footnotetext{
${ }^{36}$ M. Brignardello, 'La normativa comunitaria in materia di safety della maritime navigation', in Tranquilli-Leali \& Rosafio 2008, p. 175.

37 The rules governing security of navigation have as their object the repression of unlawful acts committed at sea with the intention of causing harm. See U. Leanza, 'International Security and Powers of Enforcement at Sea', in this book.

38 Brignardello 2008, p. 176.

39 Art. 211, para. 4, UNCLOS.
} 
which does not verify that its own ships' comply with safety of navigation rules $^{40}-$ may be authorized by the IMO to establish a marine protected area.

The latter may cover solely "a particular, clearly defined area" of the EEZ of the requesting coastal state. Moreover, it can be established for the purposes of adopting special mandatory measures for the prevention of pollution from vessels that are deemed necessary in light of the oceanographical and ecological conditions of the special area as well as its utilization, the protection of its resources and the particular character of its traffic. The request to establish a special area can be submitted when the coastal state concerned has 'reasonable grounds' for believing that in that area the rules and the standards mentioned in paragraph 1 are insufficient and hence special mandatory measures are required.

Precisely because only general criteria are laid down for identifying a special area and precisely because there are no objective conditions to be met for coming to a decision as to the adoptability of special measures aimed at preventing pollution from vessels in that area, Article 211, paragraph 6 - analogously to Articles 22, 41 and 53 UNCLOS - does not leave it up to the coastal state alone to decide at its discretion on the establishment of marine protected area and the issuing of the ad hoc measures applicable thereto. More specifically, Article 211, paragraph 6, provides that it is a matter for the competent international organization, i.e. the IMO, "to determine whether the conditions in that area correspond to the requirements set out above." Once it has obtained the IMO's authorization, the coastal state may adopt the special measures, communicating them to the said international organization and, after at least fifteen months have elapsed since that communication, enforce compliance therewith by foreign vessels navigating in the special area. ${ }^{41}$

\footnotetext{
40 Proceedings of that type would concern possible violations by a flag state of Art. 94, paras. 3-5, UNCLOS.

41 According to W.G. Vitzhum, 'Shiffssicherheit: DIE EG als potentieller Durchsetzungsdegen der IMO', Zeitschrift für ausländisches öffentliches Recht und Völkerreckt, Vol. 62, 2002, p. 170, inside the EEZ "ist ohne IMO-Zustimmung erfolgende Beschränkung des Schifffahrt in einem bestimmen Gebiet unzulässig."
} 
A cooperation mechanism between the IMO and one or more coastal Member States similar to that under Article 211, paragraph 6, UNCLOS also aimed at strengthening the safety of maritime navigation is set out in a non-binding act that has been resorted to on various occasions, i.e. the Guidelines for Identification and Designation of Particularly Sensitive Sea Areas issued by the IMO in $1991^{42}$ and amended by Resolution A.982 of 1 December $2005 .{ }^{43}$

Further to paragraph 4.4 of the Revised Guidelines, in order for a marine area to be classified as a PSSA, it must first of all meet IMO ecological criteria, social, cultural and economic criteria or scientific and educational criteria. ${ }^{44}$ The second criterion is strictly linked to the safety

42 IMO Res. A.720(17), 6 November 1991.

${ }^{43}$ It is interesting to observe that two PSSAs - that of the Sea Area around the Florida Keys, IMO Res. MEPC.98(47), 8 March 2002, and that of the Papahãnaumokuãkea Marine National Monument, IMO Res. MEPC.8(56), 5 April 2007 - were authorized by the IMO at the request of the USA, which in as much as it is not a signatory of UNCLOS, cannot in theory request the establishment of special areas under Art.211, para. 6, of the Montego Bay Convention.

44 A PSSA that fulfils all of the aforementioned interests is Papahãnaumokuãkea Marine National Monument (North-Western Hawaiian Islands), IMO Res. MEPC.8(56), supra, note 43. In fact, this area "supports a unique, dynamic coral reef ecosystem, which, thanks to its relative isolation, is among the healthiest in the world. It is one of the last remaining large-scale wilderness coral reef ecosystem on the planet and the largest coral reef ecosystem in the marginal tropical sea" (para. 3.2.1); "Parts of the area provide critical habitat for a variety of endangered or threatened species [...] These species include the critically endangered Hawaiian monk seas; the endangered sperm whale; the endangered hawksbill; leatherback and green sea turtles; the endangered short-tailed albatross; six endangered plant species and four endangered land birds" (para. 3.3.1); It "supports more than 7,000 species of fishes, plants, coral and other invertebrates" (para. 3.5.1); "It is geologically unique: The islands were created from a single plume of magma rising from a hot spot in the earth's mantle. Built up over millions of years of eruption, high volcanic islands were formed" (para. 3.11.2). Furthermore, "The NWHI are of particular importance because of their significance in Native Hawaiian history and culture. The NWHI have long been considered a sacred place in Native Hawaiian traditions, and two of the islands in particular contain important archaeological sites" (para. 3.12.1); "The NWHI are rich in underwater cultural heritage. The numerous wrecks found in the area are time capsules which capture specific elements of our seagoing past. Documents indicate that over 120 vessels and aircraft have been lost in the waters of the area" (para. 3.13.1). Eventually, "given the fact that the NWHI are remote and rich with marine and terrestrial 
of navigation because "in addition to meeting at least one of the criteria listed in 4.4, the recognized attributes of the area should be at risk from international shipping activities." 45

Unlike the special areas under Article 211, paragraph 6, UNCLOS, a PSSA must not necessarily be restricted to a clearly defined area of a given EEZ since it can extend "within and beyond the limits of the territorial sea." It follows that it is possible to establish a PSSA in the territorial sea, contiguous zone and EEZs of one or more IMO Member States. ${ }^{46}$ Moreover, it would seem possible to establish a PSSA on the high seas where beyond its territorial sea a coastal state has not established any functional zone. ${ }^{47}$ Moreover, to date that has not happened for any of the thirteen PSSAs authorized by the IMO. ${ }^{48}$

The proposals to establish a PSSA and the measures to be applied in the area in question must be submitted by the state or Member States concerned to the IMO, which "is the only international body responsible

life, they provide one of the few areas in the world where researchers can conduct largescale comparisons between human impacted marine ecosystems and un-impacted marine ecosystems" (para. 3.14.1); "The NWHI provide a model and rare benchmark of a health intact integrated ecosystem in its natural or near-natural state that may inspire Hawaiian residents as well as others to take part in ocean restoration efforts in their communities" (educational message; para. 3.16.1). In literature, on that PSSA, see J. Kraska, Maritime Powers and the Law of the Sea, Oxford University Press, Oxford, 2011, pp. 371-374.

45 IMO Res. A.982, cit., para. 5.1

46 This is the case for the following PSSAs: Wadden Sea, IMO Res. MEPC.101(48), 11 October 2002; Western European Waters, IMO Res. MEPC.121(52), 15 October 2004; Great Barrier Reef and Torres Strait, IMO Res. MEPC.133(53), 22 July 2005; Baltic Sea Area, IMO Res. MEPC.136(53), 22 July 2005; Strait of Bonifacio, IMO Res. MEPC.204(62), 15 July 2011.

47 On the question of PSSAs in zones of the high seas, see M.J. Kachel, Particularly Sensitive Sea Areas. The IMO's Role in Protecting Vulnerable Marine Areas, Springer, Berlin, 2008, pp. 274-280.

48 In addition to those mentioned above in notes 43 and 46, the following PSSAs have also been established: Archipelago of Süabana-Camaguey, IMO Res. MEPC.74(40), 25 September 1997; Sea Area around Malpelo Island, IMO Res. MEPC.97(47), 8 March 2002; Paracas National Reserve, IMO Res. MEPC-106(49), 18 July 2003; Canary Island, IMO Res. MEPC.134(53), 22 July 2005; Galapagos Archipelago, IMO Res. MEPC.135(53), 22 July 2005; The Saba Bank, IMO Res. MEPC.226(64), 5 October 2012. 
for designating areas as PSSAs and adopting protective measures." 49 The ensuing IMO resolution will contain the name of the PSSA and approval of the special protective measures as well as recommendations addressed to the other states - which should take all appropriate steps to ensure that ships flying their flag comply with the associated protective measures adopted $^{50}$ - or binding decisions. In this regard, it is important to note that for some PSSAs, the IMO had adopted compulsory measures for its members precisely in connection with the safety of navigation. For example, with reference to the Galapagos Archipelago PSSA, after having specified in the establishing resolution that that PSSA will enhance maritime safety, safety of navigation and protection of the marine environment in the area concerned, ${ }^{51}$ the IMO adopted a new mandatory SRS ${ }^{52}$ applicable to all vessels and to that end granted powers of control to the coastal state (Ecuador).

\section{The Competences Regarding Safety of Navigation Exercisable Independently by Coastal States}

Not always does the adoption by coastal states of measures aimed at reinforcing the safety of maritime navigation presuppose cooperation with the IMO or require authorization by the latter. In fact, by virtue of other provisions of conventional international law, certain competences relating to that subject are independently exercisable by the coastal states.

In this regard, a significant example is Article 234 UNCLOS on icecovered areas:

Coastal States have the right to adopt and enforce non-discriminatory laws and regulations for the prevention, reduction and control of marine pollution from vessels in ice-covered areas within the limits of the exclusive economic zone, where particularly severe

\footnotetext{
49 IMO Res. A.982, cit., para. 3.1.

${ }^{50}$ IMO Res. A.982, cit., para. 9.1.

${ }^{51}$ IMO Res. MEPC.135(53), cit., para. 3.5.

${ }^{52}$ IMO Res. MSC.229(82), 5 December 2006.
} 
climatic conditions and the presence of ice covering such areas for most of the year create obstructions or exceptional hazards to navigation, and pollution of the marine environment could cause major harm to or irreversible disturbance of the ecological balance. Such laws and regulations shall have due regard to navigation and the protection and preservation of the marine environment based on the best available scientific evidence. ${ }^{53}$

In view of how the provision is actually worded, it would be difficult for a coastal state in implementing it to abuse it for other ends by adopting national rules on the safety of navigation for reasons other than protecting the marine environment of an ice-covered area. Indeed, Article 234 UNCLOS does not lend itself to any interpretative doubts and even clarifies that an area of the EEZ will be classified as ice-covered if it is so for the majority of the year. The objective of the measures adopted in this area is to avoid shipping accidents that could cause an environmental disaster or seriously compromise the marine ecosystem. Solely if particularly severe climatic conditions and the ice actually make navigation dangerous can the latter be subject to unilateral restrictions imposed by the coastal state. Finally, the measures that one can adopt must not be discriminatory, i.e. must be applied also to ships flying the flag of the coastal

53 On Art. 234 UNCLOS, see among others: C. Lamson, 'Arctic Shipping, Marine Safety and Environmental Protection', Marine Policy, Vol. 11, 1987, pp. 3-15; D. McRae, 'The Negotiations of Article 234', in F. Griffiths (Ed.), Politics of the Northwest Passage, McGill-Queen's University Press, Montreal, 1987, pp. 98-114; R. Huebert, 'Article 234 and Marine Pollution Jurisdiction in the Arctic', in A.G. Oude Elferink \& D.R. Rothwell (Eds.), The Law of the Sea and Polar Maritime Delimitation and Jurisdiction, Martinus Nijhoff, The Hague, 2001, pp. 249-267; K. Barstenstein, "The "Arctic Exception" in the Law of the Sea Convention: A Contribution to Safer Navigation in the Northwest Passage?', Ocean Development and International Law, Vol. 42, 2011, pp. 22-52; Dux 2011, pp. 212-218; F. Borgia, Il regime giuridico dell'Artico. Una nuova frontiera per il diritto internazionale, Editoriale Scientifica, Naples, 2012, pp. 106-112; A. Caligiuri, 'L'océan Arctique entre reviviscence des politiques étatiques et recherche d'une coopération international renforcée: quel régime de protection pour son environnement?', in Andreone, Caligiuri \& Cataldi 2012, pp. 326-332; T.L. McDorman, 'National Measures for the Safety of Navigation in Arctic Waters: NORDREG, Article 234 and UNCLOS', in M.H. Nordquist et al. (Eds.), The Law of the Sea Convention: US Accession and Globalization, Martinus Nijhoff, Leiden, 2012, pp. 409-424. 
state. In short, unlike Article 211, paragraph 6, to which it has been said "forms lex specialis," ${ }^{54}$ Article 234 lays down less discretionary criteria for the adoption of national measures for the safety of navigation to the extent of making IMO-Coastal state "cooperative legislative competence" necessary. ${ }^{55}$

Moreover, among those provisions that Article 234 must be read in conjunction with systematically is Article 194, paragraph 5, UNCLOS, which requires the states parties to take measures "necessary to protect and preserve rare or fragile ecosystems as well as the habitat of depleted, threatened or endangered species and other forms of marine life." Well, in an exclusive economic zone, ice-covered or otherwise, the main addressee of that obligation is the coastal state, which more in general is granted "jurisdiction [...] with regard to the protection and preservation of the marine environment." ${ }^{56}$

It follows that the absence of a specific role for the IMO in Article 234 depends both on the conditions that the provisions lay down to limit the discretionary power of the coastal state to issue measures concerning the safety of navigation and the objective that the measures in question must have in the sense of their serving to implement the obligation to "protect and preserve rare or fragile ecosystems," an obligation that, as aforesaid, is one for the coastal state as far as an exclusive economic zone is concerned.

Similarly linked to the exercise of further coastal state competences are the safety zones measuring at most $500 \mathrm{~m}$ that can be established around artificial islands, installations and structures in the EEZ (Article 60, paragraphs 4-6, UNCLOS) or on the continental shelf (Article 80 UNCLOS), including those specially set up for marine scientific research (Article 260 UNCLOS). In effect, although those zones are de-

54 Dux 2011, p. 212.

55 See, on this point, Barstenstein 2011, p. 37; Dux 2011, p. 213 comments: "However, despite the fact that under Article 34 LOSC the Coastal State is not obliged to approach the IMO for approval of its legislation, it still may wish to do so as a matter of practically and due publicity."

56 Art. 56, para. 1b)iii, UNCLOS. 
signed above all to "ensure the safety both of navigation and the artificial islands, installations and structures," they are instrumental to the exercise of a coastal state's right "to construct and to authorize and regulate the construction, operation and use of artificial islands" as well as "to regulate, authorize and conduct marine scientific research" in the EEZ or on the continental shelf. ${ }^{57}$

Since all ships must observe the safety zones, ${ }^{58}$ UNCLOS allows the coastal state to unilaterally set them up only if, as mentioned before, their breadth does not exceed a distance of $500 \mathrm{~m}$ around them. ${ }^{59}$ If the coastal state needs to proclaim more extensive safety zones, it will have to ensure that these comply with "generally accepted international standards" or IMO recommendations. ${ }^{60}$ Therefore, also these articles set precise conditions to a coastal state's adoption of measures relating to the safety of navigation.

Among other provisions that contemplate a possibility for a coastal state to independently exercise certain competences concerning the safety of navigation, one can mention Article 9 of the International Convention on the Removal of Wrecks. ${ }^{61}$ It provides that within its own EEZ, ${ }^{62}$ the coastal state may lay down the conditions necessary to ensure that the removal of a wreck that was not flying its flag is done by the state of

57 See, on this point, A. Del Vecchio, Zona economica esclusiva e Stati costieri, Le Monnier, Florence, 1984, pp. 151-154.

${ }_{58}$ Art. 60, para. 6, UNCLOS.

59 With reference to the limits of the discretionary power to establish safety zones under Art. 60 UNCLOS, see Scalieris 2011, pp. 75-77.

${ }^{60} \mathrm{See}$, in particular, IMO Res. A.671(16), 19 October 1989. By contrast, Art. 260 UNCLOS does not permit the proclamation of safety zones extending more than $500 \mathrm{~m}$ around marine scientific research installations.

${ }^{61}$ That convention was signed in Nairobi on 18 May 2007 (not yet into force). The text can be viewed in A.V. Lowe \& S.A.G. Talmon, The Legal Order of the Oceans. Basic Documents on Law of the Sea, Hart Publishing, Oxford, 2009, pp. 867-877.

${ }^{62}$ Or if the coastal state party to the Nairobi Convention has not established an EEZ "in an area beyond and adjacent to the territorial sea of that state determined by that state in accordance with international law and extending not more than 200 nautical miles from the baselines from which the breadth of its territorial sea is measured" (Art. 1, para. 1). 
the ship's registry "in a manner that is consistent with considerations of safety and protection of the marine environment" (paragraphs 4 and 5).

Finally, there are rules on the safety of navigation that, in addition to granting competences - and imposing obligations - mainly on coastal states, urge cooperation between the latter and flag states. Falling within this category are Article 43 UNCLOS and Regulation 13 of Chapter V SOLAS on navigational and safety aids, for example, lighthouses and maritime signals. ${ }^{63}$ The first provision is applicable to international straits and the second to any area of the sea. Only the latter expressly lays down an obligation for the coastal state to put in place the navigational aids necessary to ensure a high level of safety. Both recommend the coastal states or the states bordering a strait, on the one part, and the flag states, on the other part, to cooperate in the maintenance and establishment of such navigational and safety aids as the volume of traffic justifies and the degree of risk requires. ${ }^{64}$

\section{Conclusion}

The classification and the analysis of the rules set out in international treaties on the law of the sea and IMO resolutions conducted in the above sections hereof call for a number of concluding remarks.

${ }^{63}$ In this regard see, among others, S. Zunarelli, 'Fari e segnalamenti', in Digesto delle discipline privatistiche. Sezione commerciale, Vol. 5, UTET, Turin, 1990, pp. 491-495; D.H. Anderson, 'Funding and Managing International Partnership for the Malacca and Singapore Straits, Consonant with Article 43 of the UN Convention on the Law of the Sea', Singapore Journal of International \& Comparative Law, Vol. 3, 1999, pp. 444-456; N. Oral, 'Straits Used in International Navigation, User Fees and Article 43 of the 1982 Law of the Sea Convention', Ocean Yearbook, Vol. 20, 2006, pp. 561-594; Fornari 2010, pp. 165-170; L.B. Sohn et al., Law of the Sea in a Nutshell, 2nd edn, West Publishing, St. Paul, 2010, p. 233; R. Virzo, 'Lighthouses and Lightships', in Wolfrum 2012, Vol. VI, pp. 873-876.

${ }^{64}$ In this regard, an example is the Cooperative Mechanism between the Littoral States and User States on Safety Navigation and Environmental Protection in the Straits of Malacca and Singapore of 16 August 2007. See IMO/SGP 2.1/1, in particular paras. 1819. 
As a first consideration, it can be observed, from a general point of view, that the proliferation of treaties and acts of international organizations, which include rules and standards whose application is designed to avoid incidents at sea caused by accidents, collisions, structural failure or intolerable working conditions and hours for seafarers, responds to an increased need for safety - understood in its various meanings - that characterizes the "modern risk society" ${ }^{65}$ As has been observed,

[...] the sensation of widespread danger that characterises current society has in fact given rise to the perception by public opinion of man's capacity to control not only harmful events caused by acts or omissions $[\ldots]$ but even - within certain limits - those deriving from natural disasters, whose damaging effects it is felt can at least be contained (if not totally eliminated). ${ }^{66}$

That "has generated a demand or an expectation from the community as a whole that those who can intervene to eliminate or reduce the risk should take the measures necessary to ensure safe conditions." 67

As described in the preceding sections, in connection with the safety of navigation, international law requires that those measures must be adopted or also implemented by coastal states. So, a second consideration relates precisely to the involvement of coastal states and, more specifically, the competences attributed to them to that end.

In fact, if one compares the provisions by virtue of which coastal states are obliged to cooperate with the IMO with those that permit them to independently intervene or that even prescribe them to adopt certain measures, and if one also interprets UNCLOS in a coordinated manner with other treaties and IMO resolutions, one can argue that the overcoming of the paramount role of flag states concerning the safety of maritime

65 In that sense F. Pellegrino, 'I nuovi orizzonti della sicurezza marittima', in Scritti in onore di Francesco Berlingieri, Numero speciale di Il diritto marittimo, Edizioni del Diritto Marittimo, Genoa, 2010, p. 793.

66 Ibid.

67 Ibid. 
navigation is a product 'simply' of the evolution of the general delimitation of the respective competences of the latter and coastal states. ${ }^{68}$

In other words, the classification made in Sections 3, 4 and 5 demonstrates that the competences inherent in the safety of navigation granted mainly to the coastal state and, consequently, removed from or - if linked to activities of more recently regulation - not attributed to the exclusive power of flag states are necessarily ancillary to the exercise of their sovereign rights, powers of control or jurisdiction that the current law of the sea reserves for coastal states. Indeed, as mentioned before, among the prerogatives of coastal states or states bordering straits, one can include, for example, management of safety zones proclaimed around artificial islands and installations of the EEZ or the continental shelf, the regulation in the EEZ of the safe removal of wrecks or administration of navigational aids in international straits.

On the other hand, flag states mainly retain competence to adopt measures necessary to ensure the safety of ships at sea and to check implementation of those measures, as, moreover, laid down in Article 94, paragraphs 3-5, UNCLOS. It follows that only if authorized by the IMO or acting in cooperation with the latter - under whose auspices moreover are issued the international rules and standards that the national measures adopted by flag states must comply with - may coastal states, archipelagic states or states bordering straits resort to further safety measures that affect (depending on whether what is involved is a territorial sea, archipelagic waters, international straits, a contiguous zone, an EEZ or a type of marine protected area) the right of innocent passage, transit and freedom of navigation of ships flying the flag of a third state.

The combination of competences enjoyed by the IMO, coastal states and flag states raises a third consideration. It seems, above all, that the exercise by coastal states of additional competences concerning safety, including those attributed through the filter of the IMO as the case may be, which leads to a reduction of the competences of flag states and

68 It should be stressed that also relevant for our purposes are the competences that a coastal state exercises as a port state at the request of another coastal state or the flag state. See note 10 above. 
vice versa, is based on a desire to safeguard the interests not only of the state that from time to time claims an interest, but also those of the international community as a whole.

Thus, for example, as observed above, the establishment of a PSSA presupposes that it is a marine area considered important by the IMO and hence by the international community for environmental, socio-economic, cultural, scientific or educational reasons. Accordingly, it must be an area in which one or more coastal states identify special measures for the safety of navigation, which, in view also of the phenomenon of flags of convenience and the fact that not all have ratified the relevant IMO Convention, are deemed necessary not only for the purposes of preventing ecological disasters following an oil spill, but also more banal cases of marine pollution from vessels. Think, for example, how important it is for Ecuador and the entire international community to assure the maximum level of protection of the environment and ecosystem of the Archipelago of the Galapagos, which, as the IMO resolution establishing the PSSA recites, "ha[s] been declared a national and World Heritage site, recognized world-wide for its scientific and cultural importance." 69

Similarly, the need for the international community to avoid the occurrence of serious maritime accidents likely to lead to a loss of human life or to grave harm to the marine environment can encourage cooperation between maritime powers and coastal states that for economic reasons, temporary or otherwise, do not have sophisticated and costly navigational aids or cannot manage them. Indeed, after the terrible sinking of the Dona Isabel frigate in January 1861 off Cape Spartel in the territorial sea of Morocco in which all on board perished, including 250 cadets, it was decided in $1865^{70}$ to set up an international commission along the lines of the one for navigation on the Rhine and Danube, charged with constructing and administering a lighthouse on Cape Spartel. ${ }^{71}$ More re-

${ }^{69}$ IMO Res. MEPC135 (53), para. 3.4.

70 Convention Concerning the Administration and Upholding of the Lighthouse at Cape Spartel, Tangier, 31 May 1865, which entered into force on 14 February 1867. See American Journal of International Law, Supplement, Vol. 16, 1912, pp. 14-17.

71 In this regard see D.J. Bederman, 'The Souls of International Organizations: Legal Personality and the Lighthouse at Cape Spartel', Virginia Journal of International Law, 
cently, in 2007, an agreement was concluded between the User states and states bordering the straits of Malacca and Singapore, ${ }^{72}$ which, further to Article 43 UNCLOS, made provision for the setting up of a fund for repairing, restoring and managing the navigational aids damaged by the tsunami in December 2004. ${ }^{73}$

One final consideration stems precisely from the UNCLOS provisions on the safety of navigation referring at least impliedly to safeguarding the general interests of the international community, which provisions could also be helpful in resolving some interpretive doubts in connection with Article 59 UNCLOS. ${ }^{74}$ That article pursues objectives similar to those aforementioned provisions since it is aimed at resolving disputes on the attribution or exercise of one or more residual competences that could arise in a given EEZ between the coastal state and third states. More precisely, Article 59 states as follows:

In cases where this Convention does not attribute rights or jurisdiction to the coastal State or to other States within the exclusive economic zones, and a conflicts arises between the interests of the coastal State and any other State or States, the conflict should be resolved on the basis of equity and in the light of all relevant circumstances, taking into account the respective importance of the interests involved to the parties as well as to the international community as a whole.

Well, it seems to us, analogously to what occurs for the regulation of concurrent competences regarding the safety of navigation, that the reference to the general interests of the international community could

\footnotetext{
Vol. 36, 1996, pp. 275-377, who has highlighted that it was a case of "collective adoption of responsibility by a group of states for an activity of importance for the entire global community" (p. 275).

72 See note 64 above.

73 Fornari 2010, p. 263.

74 On that provision, see - also for the other literature cited therein - the in-depth study carried out by S. Karagiannis, 'L'article 59 de la Convention des Nations Unies sur le droit de la mer (ou les mystères de la nature juridique de la zone économique exclusive)', Revue belge de droit international, Vol. 37, 2004, pp. 325-418.
} 
assume decisive importance in establishing whether the carrying on of a certain activity in an EEZ, not specifically regulated in UNCLOS, must be attributed to the coastal state or is to fall within that which appears to be the ever-increasing 'eroded' regime of freedom of the high seas.

Roberto Virzo é professor associado de International Law na Università degli Studi del Sannio (Itália), e professor de International Law of the Sea e International Organizations na University of Florida (Estados Unidos).

E-mail: roberto.virzo@unisannio.it.

Endereço Profissional: Università degli Studi del Sannio, Dipartimento DEMM, Piazza Arechi II, 82100, Benevento, Italia. 